\title{
Complementary patterns of even-skipped and fushi tarazu expression involve their differential regulation by a common set of segmentation genes in Drosophila
}

\author{
Manfred Frasch and Michael Levine \\ Department of Biological Sciences, Fairchild Center, Columbia University, New York, New York 10027 USA
}

\begin{abstract}
We have examined the position-dependent expression of two segmentation genes that contain a homeo box, even-skipped (eve) and fushi tarazu $(f t z)$. Products encoded by both genes accumulate in a series of seven transverse stripes along the anterior-posterior body axis of developing embryos. Double-staining experiments show that $e v e$ and $f t z$ proteins accumulate in complementary sets of embryonic cells. A total of eight zygotically active segmentation genes are required for the establishment and refinement of the $e v e$ and $f t z$ expression patterns during development. Mutations that affect one of the genes were always found to produce a reciprocal alteration in the other. These results suggest that the eve and ftz promoters independently "interpret" the same positional cues to give differential patterns of expression. We propose that a combination of segmentation gene products that activates the expression of $e v e$ represses the expression of $f t z$, and vice versa. This proposal is discussed in the context of a hierarchy of interactions among segmentation genes, whereby the gap genes establish asymmetric patterns of $e v e$ and $f t z$ expression in blastoderm-stage embryos, and interactions with other pair-rule genes serve to refine further the complementarity of $e v e$ and $f t z$ expression during gastrulation and germ band elongation.
\end{abstract}

[Key Words: eve and ftz expression; Drosophila; segmentation; homeo box]

Received July 23, 1987; revised version accepted September 10, 1987.

The nine pair-rule genes of Drosophila are required for the subdivision of the developing embryo into a repeating series of homologous body segments (NüssleinVolhard and Wieschaus 1980; Nüsslein-Volhard et al. 1985). Mutations in any one of these genes typically result in embryos that lack pattern elements in alternating segments. eve appears to be particularly important for the overall segmentation pattern since "strong" evemutants lack all segmental subdivisions in the middle body region (Nüsslein-Volhard et al. 1985). In contrast, null mutations in any of the other eight pair-rule genes do not completely eliminate segmentation. There is a close correspondence between the sites of eve expression in wild-type embryos and the regions deleted in eve mutants (Harding et al. 1986; Macdonald et al. 1986; Frasch et al. 1987). Using an antibody raised against a $\beta$-galactosidase-eve fusion protein, it has been shown that the eve protein is distributed in a series of seven transverse stripes at the cellular blastoderm stage (Frasch et al. 1987). These sites of expression define the odd-numbered parasegments /a parasegment corresponds to the posterior compartment of one segment and the anterior compartment of the adjacent segment; Martinez-Arias and Lawrence 1985|. The odd-numbered parasegments are deleted in weak eve mutants (i.e., hypomorphs), and only the strongest eve mutants (i.e., null alleles) delete both the odd- and even-numbered parasegments. During earlier and later periods of wild-type development, the eve protein transiently accumulates in the even-numbered parasegments as well. For example, during gastrulation a 14-stripe pattern of expression occurs whereby high levels of the eve protein are observed in the original odd-numbered parasegments and lower levels are detected in the even-numbered parasegments. Thus, there is strong and persistent expression of the eve protein in those regions where there is a strong requirement for eve gene function (the odd-numbered parasegments), and weak expression in those regions where there is only a weak genetic requirement (the even-numbered parasegments).

It has been proposed that the establishment of selective patterns of pair-rule gene expression involves a network of hierarchical interactions among several classes of segmentation genes /Carroll and Scott 1986; Howard and Ingham 1986; Harding et al. 1986; Macdonald et al. 1986; Ingham and Martinez-Arias 1986). The first step in this process is thought to involve the activities of maternally expressed genes, which are responsible for establishing the basic features of the anterior-posterior organization of the embryo (Nüsslein-Volhard 1979; 
Meinhardt 1986). Such maternal components appear to be required for the expression of zygotically active gap genes, which subdivide the embryo into broad regions that encompass several contiguous segment primordia. Gap mutants show deletions of large groups of adjacent segments. For example, mutations in the gap gene knirps (kni) result in deletions of the first through seventh abdominal segments (Nüsslein-Volhard and Wieschaus 1980).

Cross-regulatory interactions have been shown to occur among gap genes (Jäckle et al. 1986), and it has been proposed that combinations of gap gene products establish periodic patterns of pair-rule gene expression (Meinhardt 1986). The recent demonstration that gap mutants show strongly altered patterns of fushi tarazu (ftz) expression is consistent with a hierarchy of interactions whereby gap genes influence the segmentation pattern by regulating the expression of pair-rule genes (Carroll and Scott 1986; Ingham et al. 1986).

Here, we examine possible genetic mechanisms for the establishment of the periodic pattern of eve expression, as well as that of $f t z$, two genes that contain a homeo box-coding sequence (Scott and Weiner 1984; McGinnis et al. 1984a, b; Laughon and Scott 1984). Mutations in these two pair-rule genes produce reciprocal defects, in that $f z^{-}$embryos show deletions of evennumbered parasegments (Wakimoto et al. 1984; Martinez-Arias and Lawrence 1985), and "weak" eve mutants show deletions of odd-numbered parasegments (Nüsslein-Volhard et al. 1985). Simultaneous localization of $\mathrm{eve}^{+}$and $\mathrm{ftz}^{+}$products in wild-type, gastrulating embryos shows that these genes are expressed in complementary sets of embryonic cells (Harding et al. 1986; see below), as predicted by previous genetic studies. We have examined the basis for these reciprocal patterns of expression by analyzing the distribution of $e v e$ and $f t z$ proteins in various mutants that disrupt segmentation. These results suggest that the establishment of complementary patterns of eve and $f t z$ expression involves the differential regulation of these genes by a common set of segmentation loci.

\section{Results}

\section{Wild-type expression}

The eve protein is first detected after the 11 th nuclear cleavage, $\sim 2 \mathrm{hr}$ following fertilization (Frasch et al. 1987). At this time the protein is detected at uniform levels in each of the embryonic nuclei, including those located at the cortex as well as the yolk nuclei. A localized staining pattern is first detected during the 13th nuclear cleavage, whereby nuclei located in the posterior two-thirds of the embryo are more strongly stained as compared with those located more anteriorly (Fig. 1a). A rather sharp anterior boundary of staining is detected at $\sim 70 \%$ egg length / where $100 \%$ egg length corresponds to the distance from the posterior pole to the anterior pole). Over the next $\sim 20 \mathrm{~min}$, in the absence of nuclear divisions or rearrangements, a periodic pattern of eve expression gradually unfolds, whereby eve protein is local-
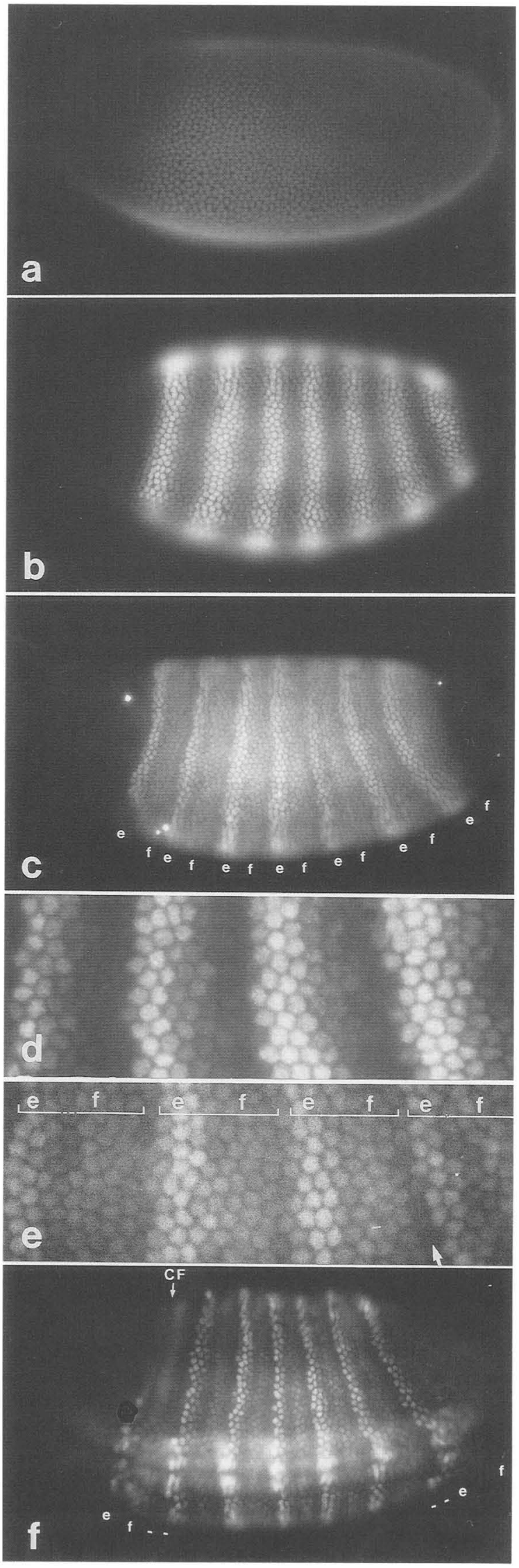

Figure 1. (See facing page for legend.) 
ized in a series of seven transverse stripes along the anterior-posterior axis (Fig. 1b). At this stage each expression stripe includes approximately four or five cells, and adjacent stripes are separated by approximately three to four cells that show lower levels of expression. Note that there is strong staining in the "interstripe" regions at this time, and the protein is actually distributed in a continuous, bell-shaped pattern. There is a refinement of this periodic pattern during gastrulation, such that each stripe gradually narrows and shows a progressively sharper anterior border. This sharpening appears to involve a gradual loss of staining from the more posterior cells of each stripe (see Fig. 10 for more details on this sharpening process). As germ band elongation begins ( $\sim 4 \mathrm{hr}$ after fertilization) seven new stripes of expression can be detected in addition to the original stripes (Frasch et al. 1987). Each of these new stripes is one to two cells wide and is much weaker than the original stripes. Both the original and new stripes gradually disappear during germ band elongation.

The $f t z$ protein is distributed in a series of seven transverse stripes and shows a "four on, four off" pattern in cellular blastoderm-stage embryos (Carroll and Scott 1985). During cleavage cycle 14 the eve and ftz expression patterns overlap (Fig. 1c). This overlap largely results from the broad, bell-shaped distribution of each eve stripe (Fig. $1 \mathrm{~b}, \mathrm{~d}$ ). Between six and seven of the approximately eight nuclei that comprise a "double segment" are stained by the eve antibody (Fig. 1d). The eve and $f t z$ stripes must overlap within at least two nuclei per double segment since each $\mathrm{ftz}$ stripe includes four nuclei at this stage (Carroll and Scott 1986). It is likely that the

Figure 1. Distribution of $e v e$ and $f t z$ proteins in wild-type embryos. Whole-mount preparations of fixed embryos were stained with affinity-purified anti-eve and anti-ftz antibodies, and visualized by indirect immunofluorescence using rhodamine-conjugated goat anti-rabbit antibodies. Embryos are oriented so that anterior is to the left and ventral is down. $(a)$ Embryo undergoing the thirteenth nuclear cleavage that was stained with the anti-eve antibody. Staining is restricted to nuclei located from $70 \%$ egg length to the posterior pole. The strongest staining occurs from $70 \%$ to $50 \%$ egg length. (b) Cellular blastoderm embryo after staining with anti-eve. The eve protein is distributed in a series of seven transverse stripes along the anterior-posterior axis. Note the broad, bell-shaped pattern of eve expression. $(c)$ Embryo just prior to the onset of gastrulation that was double-stained with anti-eve and anti-ftz antibodies. The eve expression stripes /strongly stained and designated e) have begun to sharpen at their anterior borders. The $f t z$ stripes (more weakly stained and designated f) are broader, and each encompasses an average of four cells. The $e v e$ and $f t z$ stripes partially overlap, and there are no unstained nuclei in the region from $\sim 70 \%$ to $15 \%$ egg length. (d) High-magnification view of an embryo at the same stage as that shown in $c$; the fourth through the seventh eve stripes are shown. $(e)$ High magnification of the embryo in $c$, which shows the second through fifth composite eve $+f t z$ stripes. ( $f$ ) Embryo at the onset of germ band elongation that was stained with anti-eve and anti-ftz antibodies. By this time $e v e$ and $f t z$ show reciprocal patterns of expression, and there is a gap of $\sim 1$ cell in width that separates adjacent stripes. The $f t z$ stripes coincide with the weak, transient eve stripes that are observed at this stage. (CF) Cephalic furrow. overlap is even more extensive since the broad, composite stripes of eve $+f t z$ staining are separated by a row of nuclei that show lower levels of staining (Fig. 1c and arrow, Fig. 1e). Detailed measurements of the relative positions of the eve and $f t z$ stripes in embryos that have just completed cellularization indicate that the two expression patterns are "out of register" (see Fig. 10). Similar results were obtained by staining embryos with a mixture of mouse-anti-ftz and rabbit-anti-eve antibodies, which permitted the visualization of the two patterns with different fluorescent dyes. Non-overlapping patterns begin to emerge during gastrulation, and by the onset of germ band elongation the two genes show reciprocal patterns of expression (Fig. 1f). The establishment of these complementary patterns of eve and $f t z$ expression was analyzed by examining the distribution of $e v e$ and $f t z$ proteins in a variety of segmentation mutants, as described below.

\section{Hunchback-}

The gap gene hunchback $(h b)$ is required for the establishment of both anterior and posterior body segments, including the labium and thorax as well as portions of the seventh and eighth abdominal segments (Lehmann 1985; Lehmann and Nüsslein-Volhard 1987; see Fig. 2). Parasegments 2-7 and parasegment 13 are either partially or completely deleted in $h b^{-}$mutants. These deleted regions correspond to eve expression stripes 2 (parasegment 3), 3 (parasegment 5), 4 (parasegment 7), and 7 (parasegment 13).

Embryos homozygous for a strong point mutation of $h b$ show an abnormal pattern of $e v e$ expression, which closely corresponds to the segments deleted in advanced-stage $h b^{-}$embryos. This altered eve pattern is detected during the time when selective patterns of $e v e$ expression are first established, just prior to the completion of cellularization (Fig. 3a,b). The region from $73 \%$ to $\sim 50 \%$ shows two broad bands of expression in place of the four narrower stripes seen in wild-type (Frasch et al. 1987). In addition, there is a reduction of the seventh eve stripe; the fifth and sixth stripes appear essentially normal. This eve pattern persists in gastrulating $\mathrm{hb}^{-}$ embryos (Fig. 3c), as well as those undergoing germ band elongation (data not shown). As for wild-type, $h b^{-} \mathrm{em}$ bryos show a gradual "sharpening" of the eve expression stripes during gastrulation.

It has been shown that the $f t z$ expression pattern is strongly altered in $h^{-}$embryos (Carroll and Scott 1986). Comparison of the altered eve and $f t z$ patterns reveals that they show reciprocal defects. Thus, regions in $h b^{-}$embryos where eve proteins are expressed coincide with regions where $f t z$ proteins are not expressed, and vice versa. The simultaneous staining of $h b^{-}$embryos with anti-eve and anti-ftz antibodies clearly demonstrates the complementarity of the two expression patterns (Fig. 3d).

\section{Krüppel-}

The gap gene Krüppel $(K r)$ is required for the establishment of the thorax and anterior abdomen, including each of the three thoracic segments as well as the first 


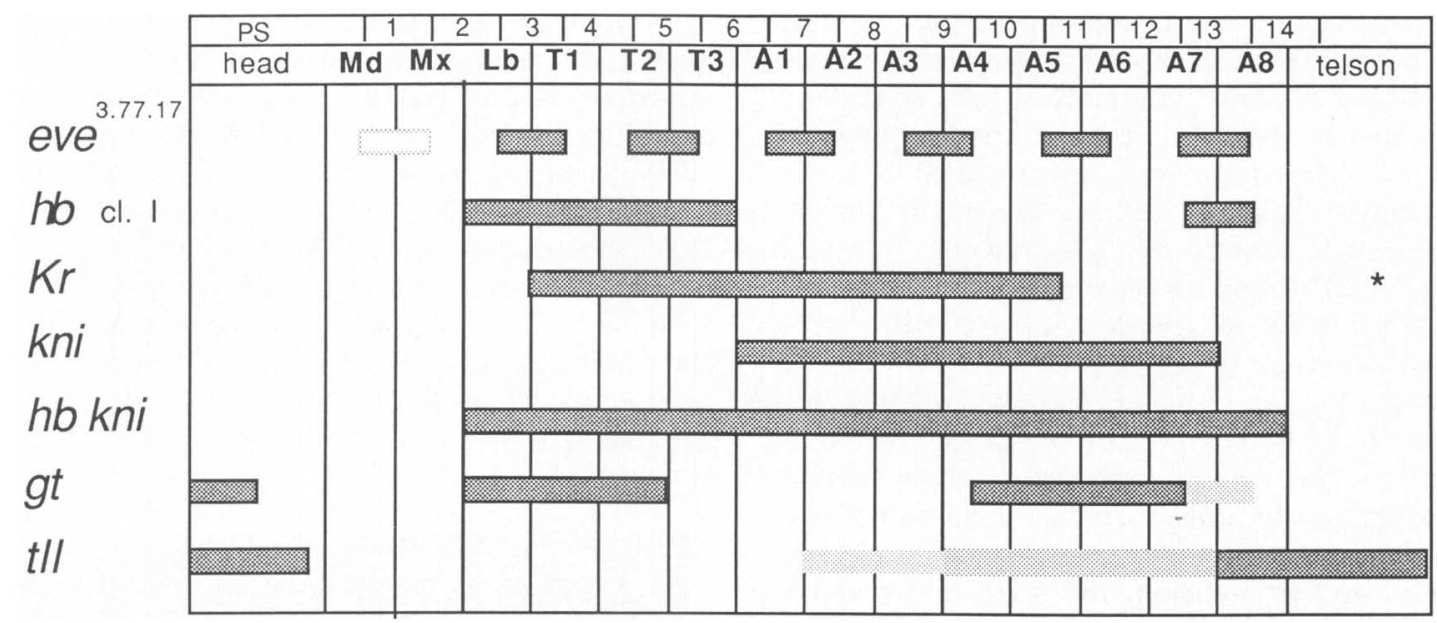

Figure 2. Domains of gap gene function. This diagram shows the pattern elements that are deleted in advanced-stage embryos for each of the indicated gap mutants, as well as the regions deleted in "weak" eve mutants. For example, the labium, thorax, and portions of A8 are deleted in $h^{-}$embryos. The top two lines relate the positions of segments with parasegments. For example, "weak" eve mutants lack portions of the labium and prothorax, which corresponds to parasegment 3 . As can be seen, each gap gene has an overlapping, but unique domain of function. Lighter bars correspond to more weakly affected segments. For example, the eighth abdominal segment and telson are deleted in $t 11^{-}$, whereas the second through seventh abdominal segments are expanded progressively toward the posterior pole. The asterisk indicates the deletion of the malpighian tubules in $\mathrm{Kr}^{-}$embryos. (Al-A8) First through eighth abdominal segments; (cl I) class I $h^{-}$mutant, which corresponds to the null phenotype (Lehmann and Nüsslein-Volhard 1987); (Lb) labium; (Md) mandible; (Mx) maxilla; (PS) parasegments; (T1-T3), the first through third thoracic segments.

five abdominal segments (Gloor 1950; Nüsslein-Volhard and Wieschaus 1980; Wieschaus et al. 1984a; Knipple et al. 1985; see Fig. 2). $\mathrm{Kr}^{-}$embryos show an abnormal pattern of eve expression, and as observed for $h b$, there is a close correspondence between the sites where the eve pattern is strongly altered, and the segments deleted in $\mathrm{Kr}^{-}$. An abnormal eve pattern is first detected during cellularization, when a prominent band of staining is detected at $\sim 35 \%$ egg length, in addition to the normal first stripe. There is an abnormally low level of staining in the region posterior to the first stripe (Fig. 4a), where the second and third stripes normally arise in wild-type (Frasch et al. 1987). After cellularization, two broad bands of eve expression are observed in place of eve stripes 2-6 (Fig. 4b); the first and seventh eve stripes appear normal.

During gastrulation each of the eve bands sharpens, and nonuniform staining becomes evident along the dorsal-ventral axis (Fig. 4c). It has been shown that the $\mathrm{ftz}$ pattern is also strongly disrupted in $\mathrm{Kr}^{-}$embryos (Carroll and Scott 1986; Ingham et al. 1986), and, as for eve, dorsal-ventral asymmetries were observed. These dorsal-ventral differences of $e v e$ and $f t z$ expression are consistent with the observation that abnormalities in the segmentation pattern of $\mathrm{Kr}^{-}$embryos are not equivalent in dorsal versus ventral tissues (Wieschaus et al. 1984a). To test the possibility that altered patterns of eve and $f t z$ expression are reciprocal in $\mathrm{Kr}^{-}$, we simultaneously stained mutant embryos with anti-eve and anti$f t z$ antibodies (Fig. 4d). As for $h b$ mutants, complementary eve and ftz patterns are observed. The extent to which these patterns are reciprocal is best illustrated by comparing eve and ftz staining in the broad anterior do- main, where the dorsal-ventral asymmetries are most pronounced. For example, the ventral region where eve staining is split into two narrower stripes is "filled" by strong staining with the anti-ftz antibody (Fig. $4 \mathrm{~d}$ ).

Subtle alterations of the eve and $f t z$ expression patterns were observed in approximately one-half of the embryos collected from $\mathrm{Kr}^{+} / \mathrm{Kr}^{-}$adults, which probably correspond to $\mathrm{Kr}^{+} / \mathrm{Kr}^{-}$heterozygotes (Fig. 4e). $\mathrm{Kr}$ heterozygotes are fully viable, although there is a dominant effect on the segmentation pattern, which includes subtle defects in the mesothorax and anterior metathorax, as well as in the second abdominal segment (Wieschaus et al. 1984a). Homeotic transformations are occasionally observed for several of the cuticular structures associated with these segments in adults. The eve and $f t z$ expression patterns are "compressed" in $\mathrm{Kr}$ heterozygotes; this region includes the third eve stripe through the fourth $\mathrm{ftz}$ stripe. Normally this domain of eve and $f t z$ expression extends from $\sim 53 \%$ to $37 \%$ egg length, but in $K r$ heterozygotes extends from only $~ 52 \%$ to $42 \%$ (see arrows, Fig. $4 \mathrm{e}$; summarized in Fig. 10). This region includes parasegments $5-8$, which overlaps with the primary domain of $\mathrm{Kr}^{+}$expression in wild-type (Knipple et al. 1985; Jäckle et al. 1987).

\section{Knirps- $^{-}$}

The gap gene knirps $(\mathrm{kni})$ is required for the segmentation of the abdomen (Nüsslein-Volhard and Wieschaus 1980; see Fig. 2). kni- embryos show abnormal eve and $f t z$ patterns that closely correspond to the segments deleted in advanced-stage mutants. After cellularization, the fourth, fifth and sixth eve stripes are essentially ab- 
sent, whereas stripes 1, 2, and 3 appear normal (Fig. $5 a, b)$. The seventh stripe is shifted toward a more anterior position (see Fig. 10). The patterns of eve and $f t z$ expression show reciprocal defects in $\mathrm{kni}^{-}$, as demonstrated by double-staining experiments with anti-eve and anti-ftz antibodies (Fig. 5c). As shown previously, the third through sixth $f t z$ expression stripes are fused into a single broad band in $\mathrm{kni}^{-}$(Carroll and Scott 1986), which coincides with the region where eve staining is absent.

A weak alteration of the eve expression pattern is also observed in heterozygous $\mathrm{kni}^{-} / \mathrm{kni}^{+}$embryos. Such embryos are fully viable and occasionally show abnormalities of the fourth abdominal segment (Lehmann 1985). The fifth eve expression stripe is strongly reduced in kni heterozygotes, and in addition, the sixth and seventh stripes are shifted to more anterior positions as compared with wild-type (Fig. 5d; summarized in Fig. 10). In kni heterozygotes, the fifth and sixth eve stripes are confined to a narrower region along the anterior-posterior axis as compared with wild-type. Thus, the embryonic fate map is "compressed" within the normal domain of $\mathrm{kni}^{+}$gene function (arrows, Fig. 5e), and there is a corresponding expansion of posterior regions of the fate map.

\section{Hunchback $^{-}$, Knirps ${ }^{-}$double mutants}

$\mathrm{hb}^{-}, \mathrm{Kr}-$ embryos lack segment boundaries and show a continuous lawn of denticle hairs, which is a phenotype similar to strong eve $e^{-}$embryos (Lehmann 1985). The altered patterns of $e v e$ and $f t z$ expression that are observed in such mutants do not appear to represent a simple addition of the eve and $f t z$ expression patterns seen in $\mathrm{hb}^{-}$ and $\mathrm{kni}^{-}$embryos. In double mutants, eve and $f t z$ proteins are not localized within stripes, but instead show continuous staining along the anterior-posterior axis (Fig. 6a,c). Both genes show approximately the same limits of expression, from $\sim 74 \%$ to $13 \%$ egg length. Within this stained interval there are regions that show

Figure 3. eve and $f t z$ expression in hunchback mutants. The presentation of embryo whole mounts is described in the legend to Fig. 1. (a) Cleavage cycle 14 embryo just prior to the completion of cellularization, which was stained with anti-eve antibody. Two broad bands of staining are seen from $73 \%$ to $50 \%$ egg length. (b) Cellular blastoderm stage mutant. There is a broad domain of eve staining from $73 \%$ to $50 \%$ egg length. The two bands observed earlier (see $a$, above) continue to show the strongest staining within this region. In wild-type, this domain contains the first four eve stripes. The fifth and sixth stripes appear normal, whereas there is a marked reduction in the staining of the seventh stripe. $(c)$ Gastrulating mutant oriented such that the ventral furrow can be seen. Each of the broad bands of staining observed in $b$ have sharpened. Note that the seventh stripe persists at a reduced level of staining. (d) Similar to $c$, except that this embryo was double-stained with anti-eve and anti-ftz antibodies. The strong staining corresponds to eve (e), whereas the weaker staining corresponds to $f t z(f)$. The region designated (e) corresponds to the reduced seventh eve stripe. somewhat reduced levels of expression (see arrows, Fig. $6 \mathrm{a}, \mathrm{c})$. The eve staining pattern rapidly diminishes during gastrulation (Fig. 6b), whereas $f t z$ staining persists at a high level (Fig. 6d), similar to that observed in wild-type. During germ band elongation, discontinuities become more pronounced in the eve and $f t z$ expression patterns, such that an anterior "stripe" can be discerned near the cephalic furrow (Fig. 6d). In addition, heterogeneities in the level of $f t z$ staining become apparent, so that a mottling of the pattern can be seen in posterior regions of the germ band. Altered patterns of $e v e$ and $f t z$ expression are also observed in $\mathrm{hb}^{-}, \mathrm{kni^{- }} / \mathrm{hb^{+ }}, \mathrm{kni^{+ }}$ heterozygotes
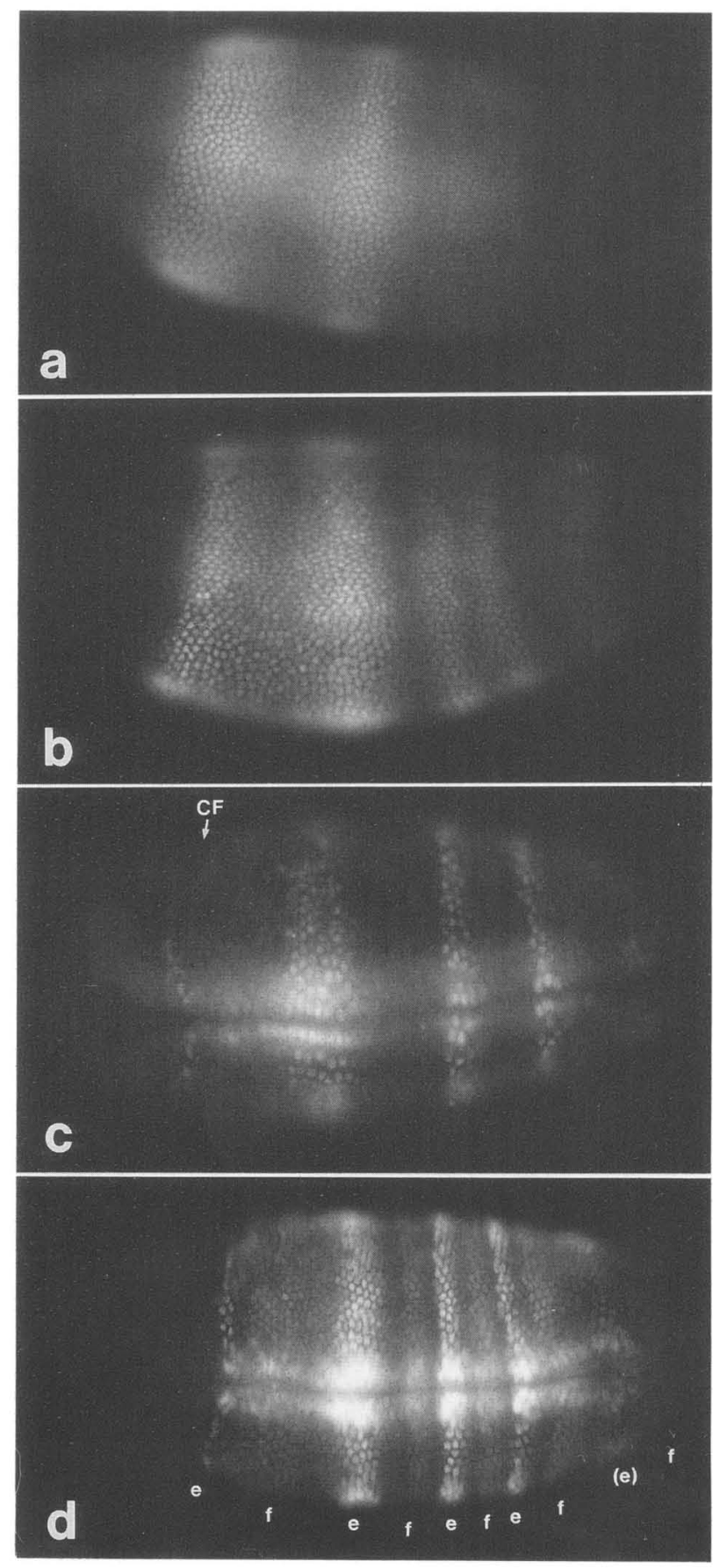
(summarized in Fig. 10), which roughly correspond to the addition of the defects seen in $h b^{-} / h b^{+}$embryos and $k n i^{-} / k n i^{+}$embryos (see Fig. 5e and summary in Fig. 10).
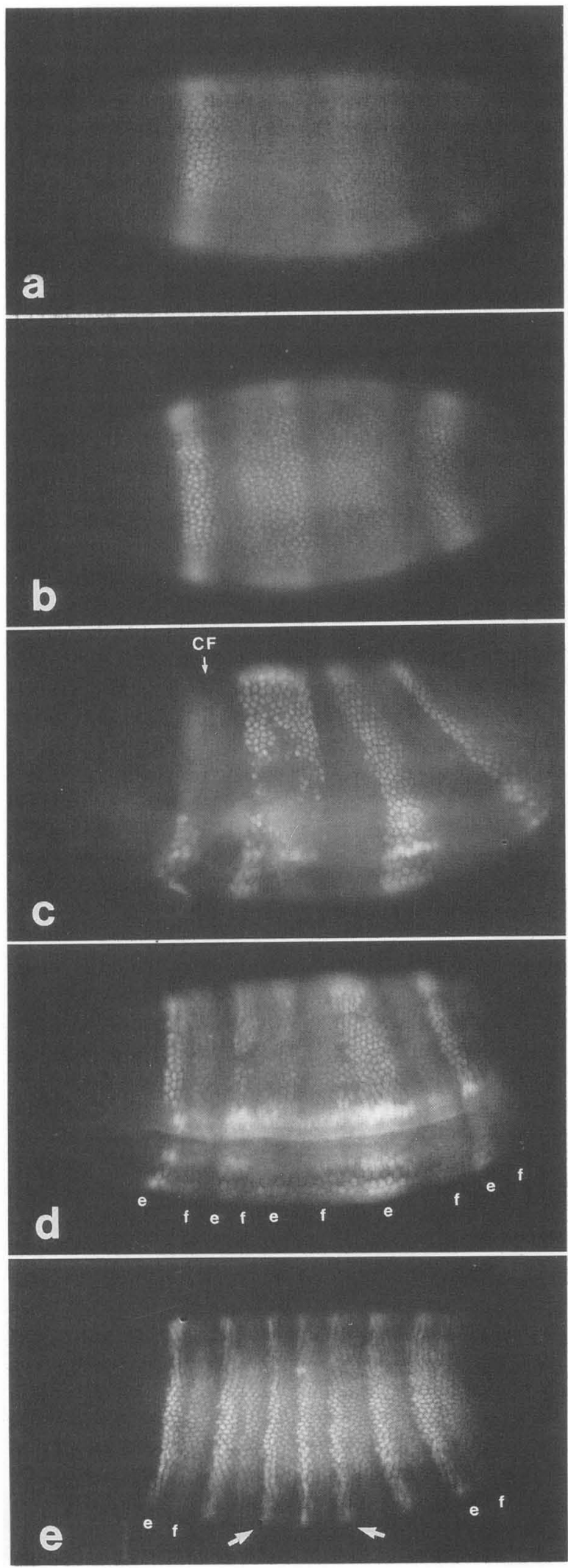

Giant $^{-}$

Mutations in the gap gene giant $(g t)$ result in anterior head defects, as well as disruptions in the fifth through seventh abdominal segments (Wieschaus et al. 1984b; Petschek et al. 1987; see Fig. 2). An abnormal eve expression pattern is first detected in $g t^{-}$embryos after cellularization (Fig. 7a). At this time, the first and second eve stripes fail to resolve, as does the broad band of staining that normally yields the fifth and sixth stripes. Moreover, the seventh stripe is strongly reduced, and never reaches wild-type levels of expression. The first and second stripes separate during gastrulation, but shortly thereafter the second stripe rapidly decays and is reduced to a sharp line of cells that show unequal levels of staining (Fig. 7b). The posterior portion of the broad, composite $5 / 6$ stripe gradually diminishes during gastrulation. By the onset of germ band elongation only the first, third, fourth, and fifth stripes appear normal, and show wild-type levels of staining.

The ftz expression pattern is also strongly altered in $g t^{-}$embryos (Carroll and Scott 1986), and during germ band elongation, the eve and $f t z$ expression patterns gradually become complementary (Fig. 7c). However, unlike the other gap mutants that were examined, extensive overlap in the $e v e$ and $f t z$ staining patterns persists during gastrulation. In particular, many of the same embryonic cells show relatively high levels of eve and $f t z$ expression within the region that contains the composite $5 / 6$ eve band (Fig. $7 \mathrm{c}$ ). Only after the onset of germ band elongation is there a loss of eve expression in this region and a persistence of $\mathrm{ftz}$ staining, thereby giving reciprocal patterns, as seen for the other gap mutants.

Figure 4. eve and $f t z$ expression in Krüppel mutants. The presentation of embryo whole mounts is described in the legend to Fig. 1. (a) Anti-eve stained cleavage cycle 14 embryo undergoing cellularization. Two prominent bands occur at $\sim 70 \%$ and $35 \%$ egg length. The region between these bands show abnormally low levels of staining. $(b)$ Embryo after completion of cellularization. The anteriormost and posteriormost eve stripes appear normal. There are two broad bands of staining between these stripes. In wild-type, this region contains the second through sixth eve stripes. (c) A gastrulating embryo that was stained with anti-eve antibody. Each of the four bands of eve expression that were detected earlier (see $b$, above), persist during this stage. However, each has become narrower and pronounced dorsal-ventral differences in the staining pattern are observed for the second band. (d) Similar to $c$, except that this embryo was double-stained with anti-eve and anti-ftz antibodies. The stronger stripes correspond to eve (designated e), whereas the weaker stripes correspond to $f t z$ (designated f). The complementarity of the two expression patterns is best illustrated by the second broad band of expression where dorsal-ventral assymetries of expression are observed for both genes. $(e)$ Cellularized $\mathrm{Kr}^{+} / \mathrm{Kr}^{-}$heterozygote after double-staining with anti-eve and anti-ftz antibodies. The arrows indicate a "compression" of $e v e$ and $f t z$ expression. This region includes the third eve stripe through the fourth $f t z$ stripe. 

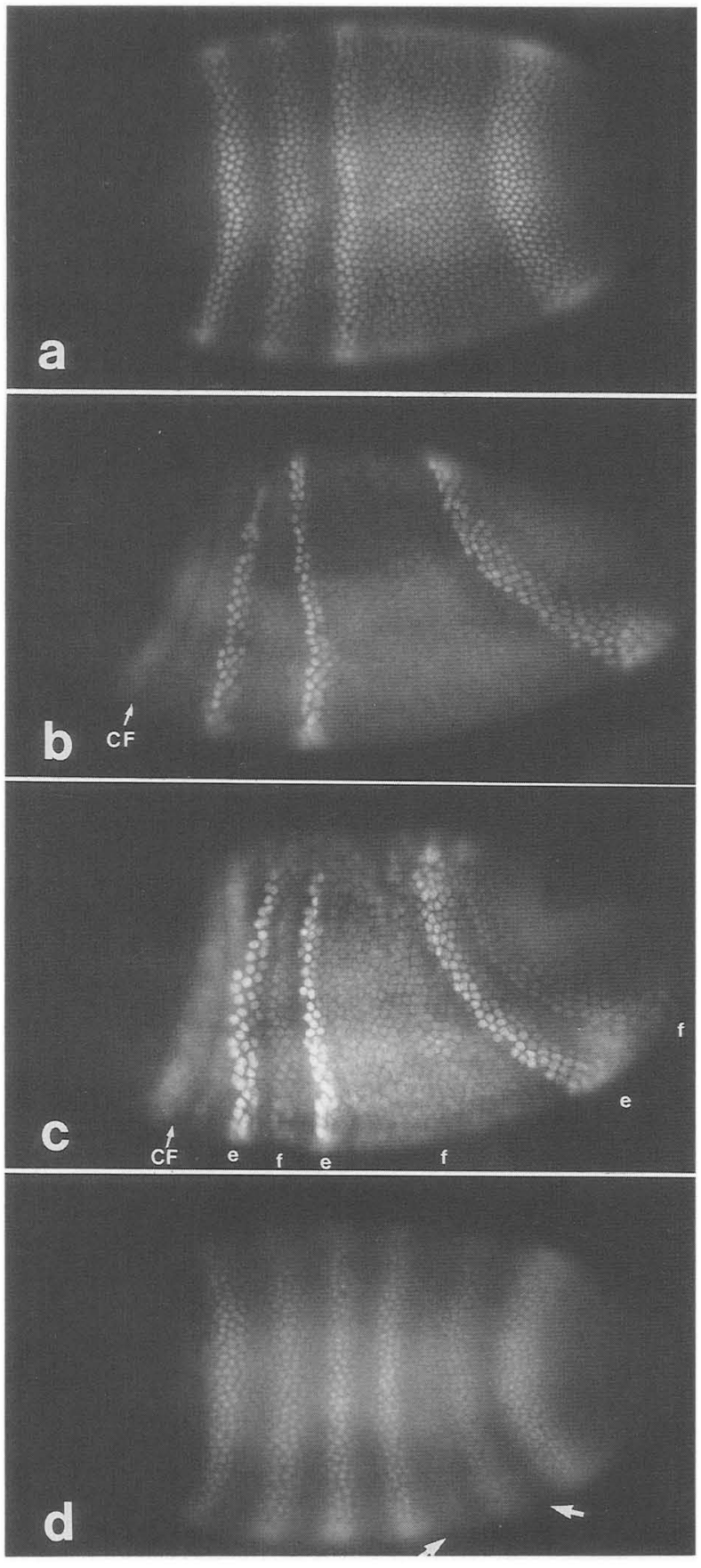

\section{Tailless}

Mutations in the gap gene tailless (tII) result in defects in the head, as well as the deletion of the eighth, ninth, and terminal abdominal segments, which is accompanied by a corresponding increase in the length of the remaining abdominal segments (Strecker et al. 1986; see Fig. 2). $t 11^{-}$embryos show only 6 , not 7 , transverse stripes of eve staining (Fig. 8a). On occasion, a partial seventh stripe is detected on the dorsal surface near the posterior pole (data not shown). There is a progressive expansion of the six remaining stripes along the anterior-posterior axis; the most marked expansion occurs
Figure 5. eve and $f t z$ expression in knirps mutants. The presentation and antibody staining of the embryos is described in the legend to Fig. 1. (a) Embryo just after the completion of cellularization. The fourth, fifth, and sixth eve stripes fail to form. Instead, the $45-30 \%$ domain shows a reduced, uniform level of staining. (b) Gastrulating embryo stained with anti-eve antibody. The first, second, third, and seventh expression stripes sharpen during this time (note that the first stripe is obscured by the cephalic furrow). Weak staining above background levels is detected in the $45-30 \%$ domain. (c) Similar to $b$, but double-stained with both anti-eve and anti-ftz antibodies. The strong staining corresponds to eve (e), whereas $f t z$ (f) shows weaker staining. The eve and ftz staining patterns are reciprocal. In particular, the $45-30 \%$ domain shows weak eve staining and strong $\mathrm{ftz}$ staining. (d) A cellular blastoderm-stage $\mathrm{kni}^{+} / \mathrm{kni}^{-}$heterozygote after staining with the anti-eve antibody. The fifth stripe shows reduced levels of staining, and the arrows indicate a compression of the fate map.

posterior to $\sim 40 \%$ egg length (summarized in Fig. 10), which results in strongly altered positions, and widths, for the fifth and sixth eve stripes (Fig. 8a). Correspondingly, there are abnormally large "gaps" of unstained cells separating the fourth and fifth stripes, as well as the fifth and sixth stripes (see arrows, Fig. 8a). By the onset of gastrulation, the altered patterns of $e v e$ and $f t z$ (Mahoney and Lengyel 1987) expression observed in $t l^{-}$are complementary (Fig. 8b).

\section{Pair-rule mutants}

Pair-rule mutants were examined to determine whether any of these genes are required for the establishment or maintenance of the normal eve expression pattern. This study involved the use of the strongest available mutant alleles for all nine pair-rule genes. None of these mutants strongly alter the establishment of the wild-type eve expression pattern, and each shows a normal or near-normal pattern during cleavage cycle 14 development. In all cases, seven transverse expression stripes are established, and at most, only relatively mild alterations in the spacing and intensity of expression are detected in cellular blastoderm-stage embryos. However, two of the genes, hairy and runt, are essential for the normal refinement and maintenance of the eve expression pattern during gastrulation, as discussed below. The only other pair-rule genes that have consistent effects on the maintenance of the eve expression pattern are eve and engrailed (en), which will be described in a separate report (Warrior et al., in prep.). Mutations in the pairrule genes $f t z$, paired, odd-skipped, odd-paired, and sloppy paired do not appear to affect the establishment or maintenance of the eve pattern.

In runt ${ }^{-}$embryos an abnormal pattern of eve expression is first detected after cellularization, when the fifth expression stripe is narrower and weaker than in wildtype. Just prior to gastrulation, each of the eve stripes, except 5, broadens and encompasses an average of five cells. In addition, irregularities in the spacing of adjacent stripes can be observed. Normally at this stage in development the eve pattern shows a "four on/four off" arrangement, and the stripes begin to sharpen at their an- 

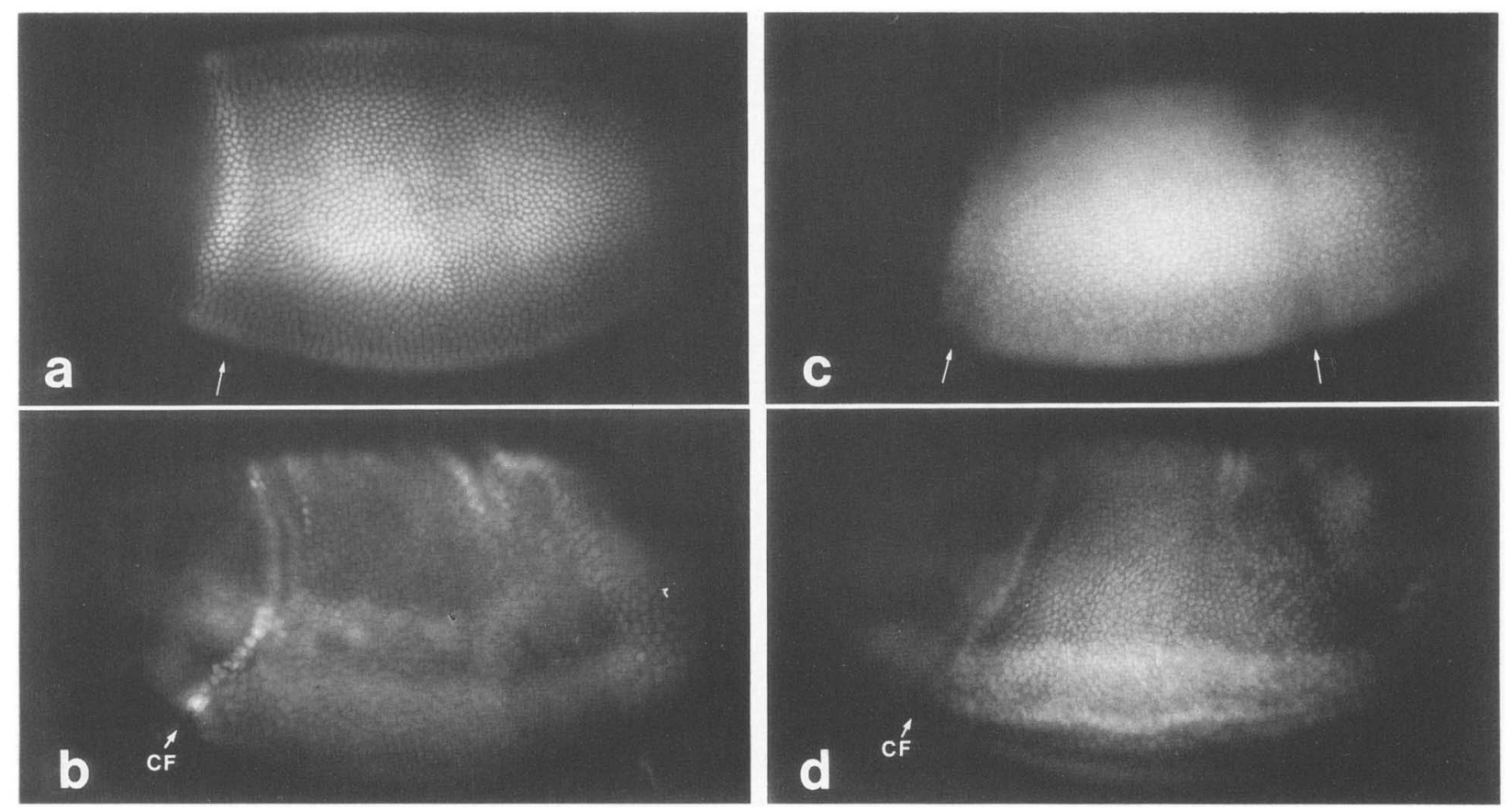

Figure 6. eve and $f t z$ expression in hunchback, knirps ${ }^{-}$double mutants. The presentation of embryo whole mounts is described in the legend to Fig. 1. $(a, c)$ Cellular blastoderm-stage double mutants stained with anti-eve $(a)$, and anti-ftz $(c)$. Both proteins are broadly distributed along the anterior-posterior axis and fail to show discrete stripes. However, some discontinuities in the staining patterns can be observed (arrows).(b, d) Gastrulating embryos stained with anti-eve (b), and anti-ftz $(d)$. There is a premature reduction in the eve staining pattern, whereas ftz expression persists at a high level during this time.

terior borders (see Fig. 1b,c). In contrast, in runt ${ }^{-}$, both the anterior and posterior margins of each expression stripe "sharpen" after cellularization (i.e., see arrows, Fig. 9a). During gastrulation, there are pair-wise fusions of adjacent stripes, particularly 6 and 7 (Fig. 9b), and irregularities in the spacing between stripes become more pronounced. For example, the gap separating the fourth and fifth stripes is significantly broader than normal.

An abnormal eve pattern is also detected in hairy mutants after cellularization. At this time the second and fifth eve stripes show reduced levels of staining, whereas the remaining stripes appear normal (Fig. 9c). During gastrulation there is a rapid decay of the overall eve expression pattern, and only weak staining of the first, third, and fourth stripes can be observed at the onset of germ band elongation (Fig. 9d). In contrast, wild-type embryos of similar age show strong expression of each of the seven stripes, which persist during germ band elongation (see Fig. 1c). Double staining of hairy ${ }^{-}$and runt ${ }^{-}$ embryos with anti-eve and anti-ftz antibodies reveals complementary patterns of eve and ftz expression in these mutants (data not shown). Thus, in runt ${ }^{-}$there is a premature narrowing, and loss, of the ftz expression stripes, whereas in $h^{-}$the $f t z$ stripes are broad and persist during gastrulation and germ band elongation (Carroll and Scott 1986).

\section{Discussion}

We have examined the distribution of the eve protein in mutants for most of the known zygotically active seg- mentation genes (Jürgens et al. 1984; Nüsslein-Volhard et al. 1984; Wieschaus et al. 1984b|. Of the mutants analyzed (summarized in Table 1), less than half $(9 / 19)$ have a discernible effect on eve expression: five disrupt the establishment of the eve pattern during cellularization, whereas an additional four alter the maintenance and/or "refinement" of the eve pattern during gastrulation (summarized in Fig. 10). The nature of the altered eve patterns observed in these mutants is consistent with the occurrence of a hierarchy of interactions among segmentation genes, whereby the gap genes control segmentation indirectly by influencing the expression of pair-rule genes such as eve.

\section{Hierarchy of interactions}

It has been proposed that the subdivision of the embryo into a repeating series of homologous body segments involves hierarchical interactions among several classes of early acting genes (Ingham and Martinez-Arias 1986; Meinhardt 1986). In particular, maternally contributed factors are thought to be responsible for the expression of gap genes, which in turn establish selective patterns of pair-rule gene expression. The pair-rule genes might implement segmentation by regulating the expression of engrailed, as well as segment polarity genes, which are required for the establishment of segment boundaries and the morphogenesis of other segmentally repeated pattern elements (Harding et al. 1986; Ingham et al. 1986). Consistent with this model is the demonstration that mutations in each of the known gap genes strongly 

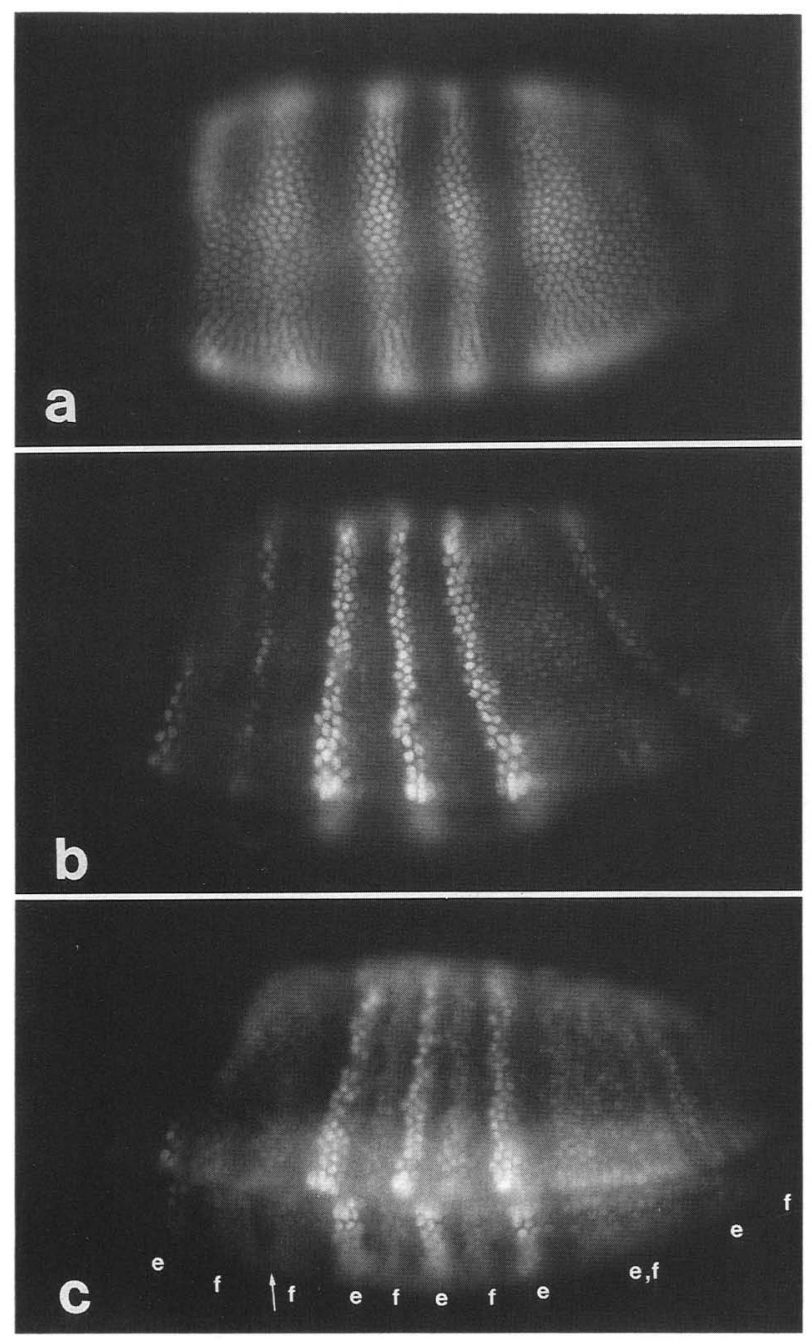

Figure 7. eve and $f t z$ expression in giant mutants. The presentation of embryo whole mounts is described in the legend to Fig. 1. (a) Cellular blastoderm-stage embryo after staining with anti-eve. Composite bands are seen for stripes $1 / 2$ and $5 / 6 .|b|$ Gastrulating embryo stained with anti-eve. The first, third, fourth, and fifth stripes appear normal, whereas the second, sixth, and seventh show strongly reduced levels of staining. Note the sharp, heterogenous staining of the second stripe. $|c|$ Similar to $b$, except that the embryo was double-stained with anti-eve and anti-ftz antibodies. Nearly reciprocal staining patterns are observed, although the region between the fifth and seventh eve stripes shows relatively strong staining with both eve and $\mathrm{ftz}$ antibodies (labeled e,f). The arrow indicates a narrow gap in a broad band of $f t z$ staining, which corresponds to the position where the sharp second eve stripe is observed at slightly earlier stages (see $b$, above).

perturb the eve expression pattern during cellularization, whereas mutations in pair-rule genes and segment polarity genes do not significantly alter the establishment of the eve pattern. Mutations in four of the nine known pair-rule genes affect the refinement of the eve pattern during gastrulation, and none of the segment polarity mutants that were examined have any detectable effect on eve expression. The effects of these different

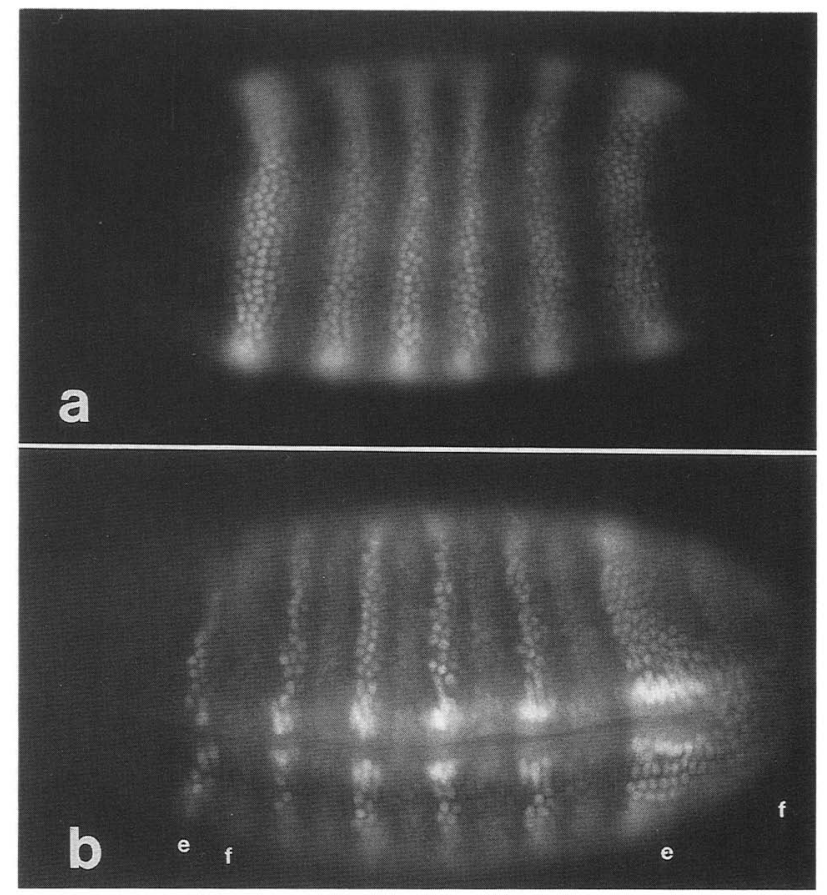

Figure 8. eve and $f t z$ expression in tailless mutants. The presentation of embryo whole mounts is described in the legend to Fig. 1. (a) Cellular blastoderm-stage cmbryo after staining with anti-eve. Only six stripes of expression are observed. These stripes, particularly 5 and 6 , are shifted toward the postcrior pole. Abnormally broad gaps occur between stripes 4 and 5 , as well as 5 and 6 . (b) Gastrulating embryo that was doublestained with anti-eve and anti-ftz antibodies. The embryo is orientcd such that the ventral furrow can be seen. Reciprocal patterns of eve and ftz staining are observed.

classes of segmentation genes on the eve expression pattern suggest a "hierarchy of function" among the segmentation genes whereby the gap genes regulate the pair-rule genes, which in turn, might regulate the segment polarity genes. It is possible that this functional hierarchy involves a temporal sequence of interactions, such that the gap genes function prior to the pair-rule genes. Consistent with this possibility is the observation that, in general, gap mutants disrupt the eve expression pattern during cellularization, whereas pair-rule mutants show altered patterns of eve expression at later stages of development.

\section{Differential regulation of eve and $\mathrm{ftz}$}

Although $e v e$ and $f t z$ products accumulate in essentially complementary sets of embryonic cells, their overall patterns of expression are remarkably similar. eve and $f t z$ transcripts are first detected during cleavage cycle 10 , when they are both uniformly distributed along the anterior-posterior axis (Hafen et al. 1984; Harding et al. 1986; Macdonald et al. 1986). Localized transcript distribution patterns are not observed until the beginning of cleavage cycle 14, and periodic expression patterns gradually evolve during cellularization. Once established, 

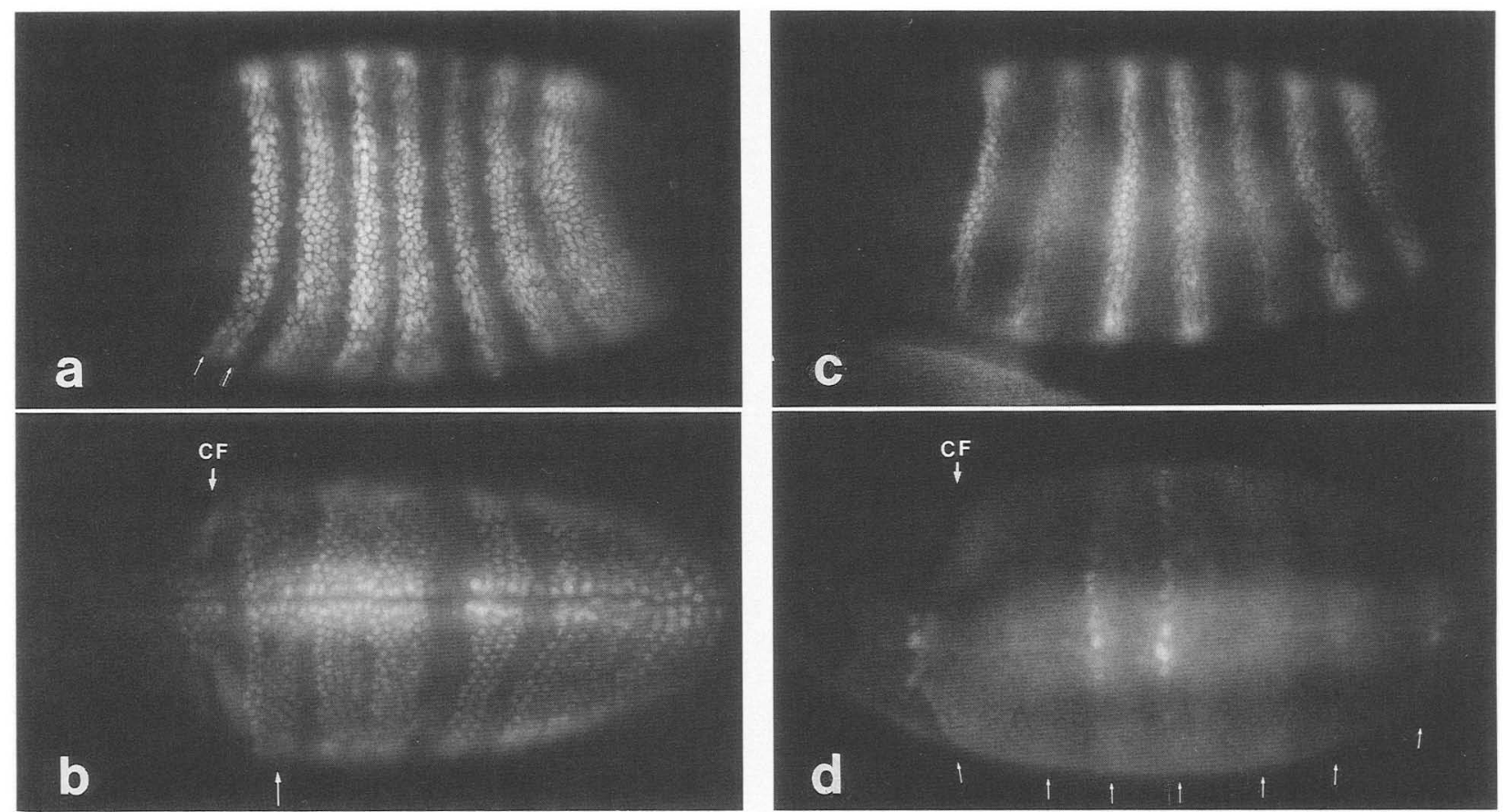

Figure 9. eve and $f t z$ expression in pair-rule mutants. The presentation of embryo whole mounts is described in the legend to Fig. 1. $(a, b)$ runt $^{-}$embryos after staining with the anti-eve antibody. $(a \mid$ Cellular blastoderm-stage. The fifth eve stripe is narrower than in wild type, and each of the stripes shows a sharper posterior border than normal (i.e., arrows; compare with Fig. 1b). (b) Gastrulating embryo oriented so that the ventral furrow can be seen. Each of the eve stripes broadens during gastrulation, resulting in pair-wise fusions and irregularities in the spacing between adjacent stripes. The central regions of each stripe are less strongly stained than the margins (e.g., arrow). (c, d) hairy- embryos stained with the anti-eve antibody. (c) Cellular blastoderm-stage embryo. The second and fifth expression stripes show slightly reduced levels of staining. (d) Ventral surface of a gastrulating embryo. There is a premature loss of eve staining. The arrows indicate the sites of expression seen in wild type. At this time only the first, third, and fourth stripes show residual nuclear staining.

the eve and $f t z$ expression stripes become progressively more refined during gastrulation, and successively diminish during germ band elongation.

The overall similarity of the eve and $f t z$ expression pattcrns suggests that the regulation of the two genes is closely coupled. A possible explanation for this coupling is that the two genes might directly regulate each others expression. For example, high levels of $e v e^{+}$products might prevent the accumulation of $\mathrm{ftz}^{+}$products, thereby restricting $\mathrm{ftz}$ expression to a complementary set of cells. Thus, mutations that perturb the expression of $e v e$ would result in a reciprocal alteration of the $f t z$ pattern. This explanation seems unlikely since eve expression is normal in $\mathrm{ftz}^{-}$embryos, and the establishment of the $f t z$ pattern is essentially normal in $e v e^{-}$ (Harding et al. 1986). A second hypothesis is that a common set of segmentation genes differentially regulate $e v e$ and $f t z$ expression such that a combination of gene products that activates eve, represses the expression of $f t z$, and vice versa. Based on the results presented in this study we favor the latter hypothesis.

The nine zygotically active genes required for the wild-type pattern of $e v e$ expression are the same genes that regulate $\mathrm{ftz}$ (Carroll and Scott 1986); none of the segmentation genes that were tested alter only one of the patterns. Mutations that affect one of the genes were always found to produce a reciprocal alteration in the other. The only exception to this rule might be the apparent negative regulation of eve by engrailed, which occurs at the end of germ band clongation (Harding et al. 1986). This suggests that the eve and ftz promoters independently "interpret" the same positional cues to give complementary patterns of expression during development. We propose that the gap genes are responsible for establishing eve and $f t z$ expression patterns that are "out of register" during cellularization (see summary Fig. 10); a combination of gap gene products that positively regulate eve negatively regulate $f t z$, and vice versa. The pair-rule genes do not appear to play a major role in the establishment of asymmetric eve and ftz expression patterns since mutations in pair-rule genes do not dramatically alter the eve pattern prior to gastrulation. Instead, the pair-rule genes, particularly runt, hairy, and eve, are involved in the refinement of the eve and $f t z$ patterns so that they become completely complementary during gastrulation (summarized in Fig. 10).

\section{Regulation by the gap genes}

Gap genes clearly play a crucial role in establishing periodic domains of gene expression. A particularly striking example of this requirement is the finding that eve and $f t z$ proteins are uniformly distributed along the anterior-posterior axis of cellular blastoderm stage $h^{-}$, 
$\mathrm{kni}^{-}$double mutants (Fig. 6a,b). It is possible that gap genes exert a relatively direct influence on pair-rule gene expression since there is only a short lag (less than 30 $\mathrm{min}$ ) between the time when the gap genes $h b$ and $K r$ are first expressed in wild-type (Knipple et al. 1985; Tautz et al. 1987), and when an altered pattern of eve expression is first observed in $\mathrm{hb}^{-}$and $\mathrm{Kr}^{-}$embryos.

The demonstration of cross-regulatory interactions among gap genes (Jäckle et al. 1986) complicates the interpretation of the altered patterns of eve and $f t z$ expression seen in gap mutants. Thus, it is unclear to what extent an abnormal pattern of eve expression is the direct result of removing a given gap gene function, or an indirect consequence of altering the distribution of other gap gene products. The patterns of eve expression observed in the various gap mutants can be interpreted according to the occurrence of regulatory interactions among the gap genes. For example, the eve pattern observed in $t 1^{-}$embryos might result not only from the absence of $t 11^{+}$products, but also as an indirect consequence of an altered distribution of products encoded by the neighboring gap gene kni (see Fig. 2). Thus, $\mathrm{tl}^{+}$ products might be required for specifying the seventh eve stripe, and for repressing the expression of kni so that its expression is restricted to more anterior regions. In $t 1^{-}$embryos this would result in the absence of the seventh eve stripe, and a posterior expansion of the kni domain of expression. The posterior shift of the fourth, fifth, and sixth eve stripes observed in $t^{-} 1^{-}$embryos might result from such a posterior expansion of $\mathrm{kni}^{+}$ac- tivity. Such shifts in the positions of the "unaffected" eve stripes are also observed in each of the other gap mutants (see Fig. 10).

It is not known how gap genes might provide sufficient informational content to establish diverse, periodic patterns of pair-rule gene expression (e.g., Fig. 11). For example, the gap gene kni is required for the fourth through sixth eve stripes and the third through sixth $f t z$ stripes (Fig. 5). The eve and $f t z$ patterns that are observed in $\mathrm{kni}^{-}$mutants suggest that $\mathrm{kni}^{+}$product activates eve and represses $f t z$. It is not clear how such differential regulation generates an organized set of eve and $f t z$ stripes. One possibility is that $\mathrm{kni}$ proteins are not uniformly distributed; perhaps gap proteins are themselves localized within crude or transient pair-rule boundaries. Transcripts encoded by $h b$ and $K r$ do not display uniform distribution patterns (Knipple et al. 1985; Tautz et al. 1987), and it is possible that their proteins will show even more striking variations of expression.

It has been proposed that boundaries between adjacent sites of gap gene expression play an important role in organizing periodic domains of gene expression. A major drawback of this proposal is that the known gap genes do not appear to provide enough boundaries to establish periodic eve and $f t z$ patterns that include a total of seven stripes. There are several explanations for this apparent discrepancy. One possibility is that the gap genes act in concert with maternal cues, such as bicoid (Frohnhöfer et al. 1986), to regulate $e v e$ and $f t z$. Alternatively, additional zygotically active genes of unknown identity

Table 1. Summary of segmentation mutants analyzed

\begin{tabular}{|c|c|c|c|}
\hline & \multicolumn{3}{|c|}{ Alteration of the eve pattern in } \\
\hline & cellular blastoderm & & gastrula \\
\hline $\begin{array}{l}\text { Gap mutants } \\
\text { hunchback }\left(h b^{14 F 21}\right) \\
\text { Krüppel }\left(K r^{1}\right) \\
\text { knirps }\left(k n i^{I I D 48}\right) \\
\text { hb, kni double mutant }\left(h b^{7 M 48}, k n i^{I D 48}\right) \\
\text { giant }\left(g t^{\text {YA82 })}\right. \\
\text { tailless }\left(t l l^{1}\right)\end{array}$ & $\begin{array}{l}\text { strong } \\
\text { strong } \\
\text { strong } \\
\text { strong } \\
\text { strong } \\
\text { strong }\end{array}$ & & $\begin{array}{l}\text { strong } \\
\text { strong } \\
\text { strong } \\
\text { strong } \\
\text { strong } \\
\text { strong }\end{array}$ \\
\hline 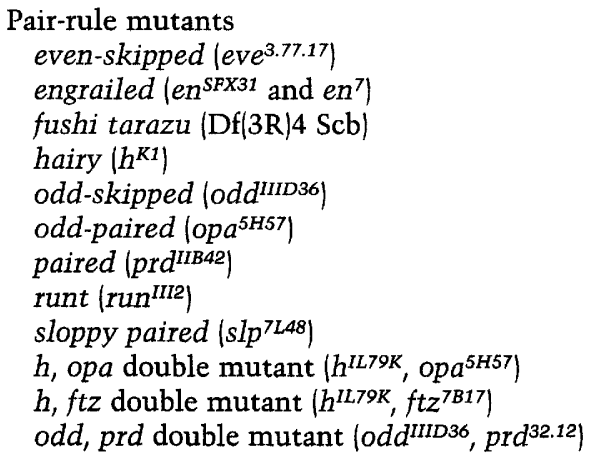 & $\begin{array}{l}\text { subtle } \\
\text { mild and variable } \\
\text { subtle } \\
\text { mild } \\
\text { subtle } \\
\text { subtle } \\
\text { subtle } \\
\text { mild } \\
\text { subtle } \\
\text { subtle }\end{array}$ & $\begin{array}{l}\text { like } h \\
\text { like } h\end{array}$ & $\begin{array}{l}\text { strong } \\
\text { mild } \\
\text { none } \\
\text { strong } \\
\text { none } \\
\text { none } \\
\text { none } \\
\text { strong } \\
\text { none }\end{array}$ \\
\hline 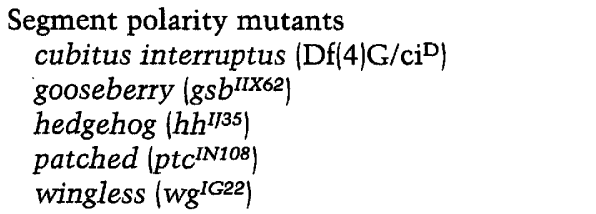 & $\begin{array}{l}\text { none } \\
\text { none } \\
\text { none } \\
\text { none } \\
\text { none }\end{array}$ & & $\begin{array}{l}\text { none } \\
\text { none } \\
\text { none } \\
\text { none } \\
\text { none }\end{array}$ \\
\hline
\end{tabular}


might mediate the regulation of the pair-rule genes by the gap genes. And finally, the establishment of additional gap gene "boundaries" could involve a temporal and/or functional hierarchy of gap gene interactions. Additional studies of gap and pair-rule gene expression in various mutants and in mutant combinations will be required to distinguish among these possibilities.

Regulation by the pair-rule genes

As discussed above, the pair-rule genes appear to be involved in the refinement of the eve and $f t z$ expression patterns during gastrulation. As for the gap genes, the pair-rule genes runt, hairy, and eve appear to exert opposite effects on $e v e$ and $f t z$ expression. runt ${ }^{+}$products either directly or indirectly repress the expression of eve, and positively regulate $f t z$. Thus, $e v e^{+}$products are over-expressed in gastrulating runt ${ }^{-}$embryos, whereas $f t z$ products disappear prematurely. In contrast, hairy exerts a positive effect on $e v e$ expression and a negative effect on $f t z$, in that $e v e$ products prematurely disappear in hairy ${ }^{-}$, whereas $f t z$ products are overexpressed. hairy and runt mutations alter the $f t z$ expression pattern upon cellularization (Carroll and Scott 1986), whereas the eve pattern is not strongly disrupted in these mutants until

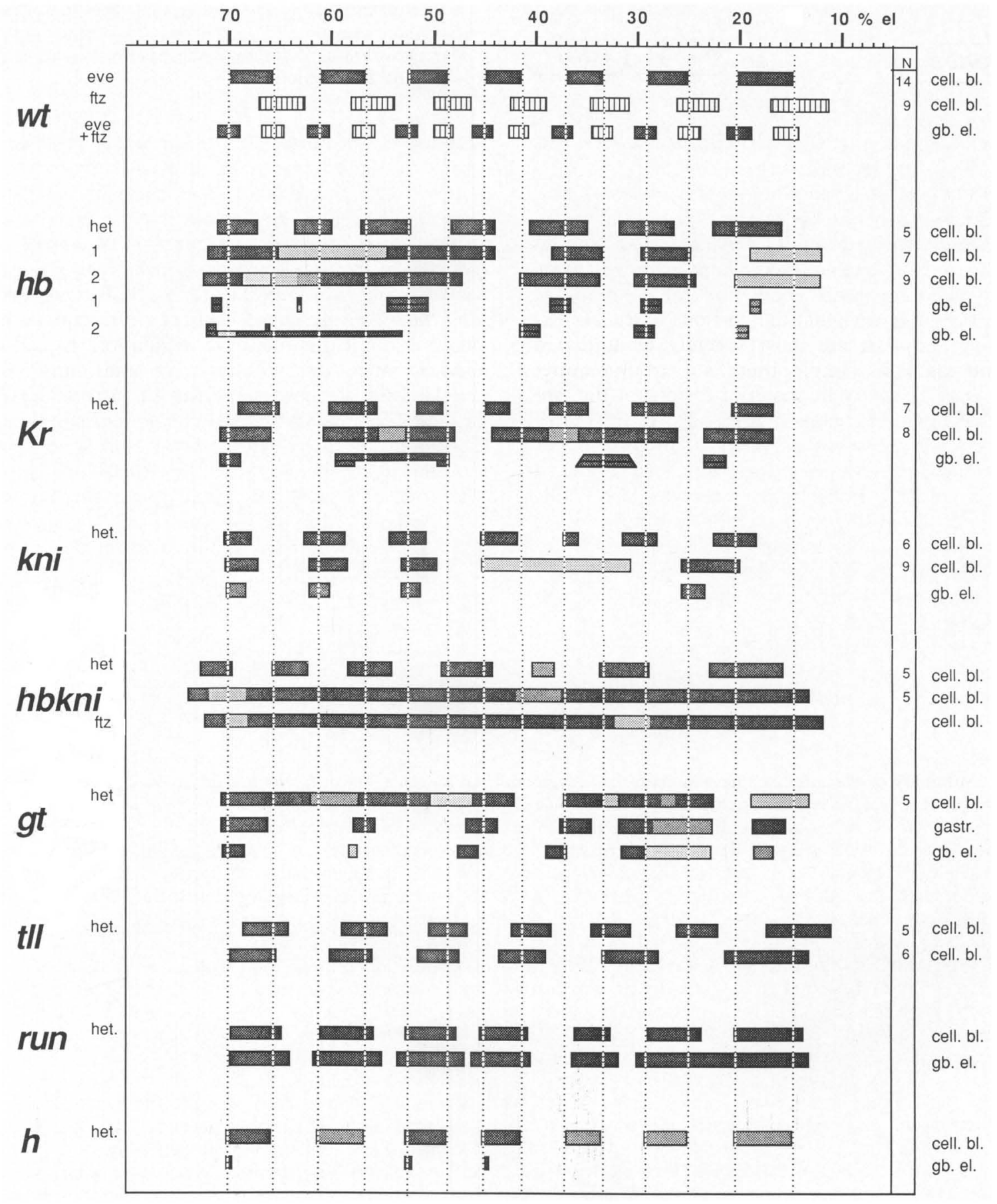

Figure 10. (See facing page for legend.) 


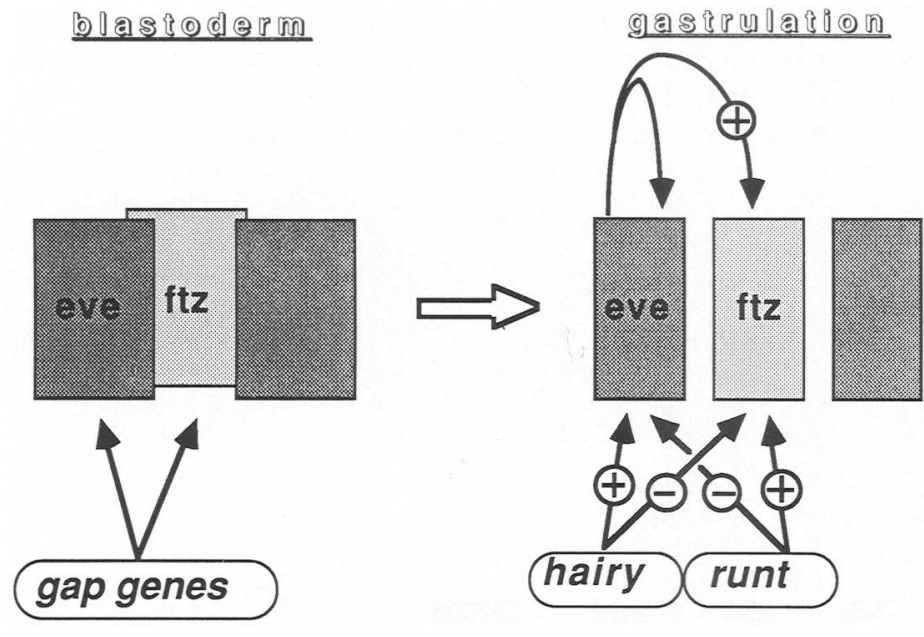

Figure 11. Summary of interactions among the segmentation genes. A combination of gap gene products that activates eve, represses $f t z$, and vice versa. In this way, asymmetric "out of register" patterns of $e v e$ and $f t z$ expression are established during cellularization. Differential regulation of eve and $f t z$ by the pair-rule genes runt, hairy, and $e v e$ are thought to be responsible for refining the eve and $f t z$ patterns so that they become perfectly complementary during gastrulation. gastrulation. The regulatory relationships between eve, ftz, hairy, and runt are summarized in Fig. 11 .

It has been previously shown that there is a differential requirement for runt ${ }^{+}$gene activity along the anterior-posterior axis of developing embryos (Gergen and Wieschaus 1986). There appears to be a close correspondence between the regions where runt ${ }^{+}$gene function is most critically required, and the portions of the eve expression pattern that are most severely disrupted in runt ${ }^{-}$embryos. For example, there is a strong requirement for runt $t^{+}$activity in posterior regions of the embryo, including those regions that give rise to the fourth through seventh abdominal segments. This corresponds to the sixth and seventh eve stripes, which are fused and strongly overexpressed in runt ${ }^{-}$embryos (Fig. 9a,b). Moreover, advanced-stage runt- embryos show periodic deletions of cuticular structures, and mirror-image duplications of the remaining pattern elements (Gergen and Wieschaus 1986). In runt ${ }^{-}$, both the anterior and posterior borders of each eve stripe become progressively sharper during gastrulation (Fig. 9a,b), whereas in wildtype only the posterior border sharpens (Fig. 1b,c). The uniform sharpening of both borders in runt- might cor- respond to the mirror image duplications of cuticular structures seen in older embryos.

It has been previously shown that hairy ${ }^{+}$products are required for the narrowing of the $f t z$ expression stripes during gastrulation, and that $\mathrm{ftz}^{+}$products are overexpressed in hairy ${ }^{-}$embryos (Carroll and Scott 1986; Howard and Ingham 1986). On this basis it was proposed that hairy exerts a negative effect on $\mathrm{ftz}$ expression. It is possible that this negative regulation is cell-autonomous, since the wild-type $f t z$ and hairy patterns overlap, but are not coincident. In gastrulating hairy ${ }^{-}$ embryos, $f t z$ products persist at high levels in those cells that might normally express hairy. Here we have shown that hairy has the opposite effect on the eve pattern, in that there is a premature loss of eve products in gastrulating hairy ${ }^{-}$embryos. Therefore it appears that hairy is required for the normal maintenance of the eve expression pattern during gastrulation.

$\mathrm{Kr}^{-}$embryos show an altered pattern of hairy expression (Ingham et al. 1986), similar to the disruptions seen for $e v e$ and $f t z$. It is likely that mutations in the other gap genes also alter hairy, and that gap mutants disrupt the pattern of runt expression as well. Such alterations

Figure 10. Summary of $e v e$ and $f t z$ expression patterns in segmentation mutants. eve or $f t z$-stained embryos were photographed in a central plane of focus, and the expression stripes were measured with respect to the anterior and posterior poles. An egg length of $100 \%$ corresponds to the anterior pole, and $0 \%$ corresponds to the posterior pole. The numbers (N) of each genotype and stage that were measured are shown in the right column. The indicated locations of each site of $e v e$ or $f t z$ antibody staining are based on an average of the measurements. The standard deviations were an average of $1.6 \%$ egg length for the wild-type eve stripes, and an average of $0.8 \%$ egg length for the wild-type $f t z$ stripes. The positions of staining during gastrulation and germ band elongation were inferred from the measurements of cellular blastoderm-stage embryos. The filled bars correspond to eve staining, and the striped bars to $f t z$. In cellular blastoderm-stage embryos the ftz pattern shows a "four on/four" arrangement, whereas the eve pattern shows a broader, bell-shaped distribution. At this time the two patterns overlap by one or two cells (compare Fig. 1d with Fig. 1e). The establishment of complementary eve and $f t z$ stripes during gastrulation appears to involve a narrowing of the posterior borders for both the eve and $f t z$ stripes. In addition, there appears to be an enhancement in the levels of eve staining in the anterior-most nuclei of each of the eve stripes, resulting in a slight anterior shift of the eve pattern. Only the eve pattern is presented for each of the indicated mutants. The first pattern shown for each mutant corresponds to embryos that are heterozygous for the mutant allele in question (het.). The other patterns correspond to homozygous mutants. Dorsal-ventral differences of eve staining is observed in $h b$ and $K r$ mutants. Dorsal patterns of eve staining are shown above the midline of each bar, whereas ventral differences are shown below the midline. For $h b$, the numbers 1 and 2 correspond to two different mutant patterns that are observed in hb14F21 homozygotes. Number 1 corresponds to the pattern shown in Fig. 3c, d, and is essentially identical to the pattern obtained in homozygotes for a deficiency of $h b$. Increasing darkness of the bars corresponds to increasing levels of eve staining. (cell. bl.) cellular blastoderm-stage embryos; (gastr.) gastrulating embryos; (gb. el.) embryos undergoing germ band elongation; (het.) embryos heterozygous for the mutant allele in question; (N) number of embryos measured; (\% el) percent egg length relative to the anterior and posterior poles. 
in the distribution of runt and hairy products should nonetheless give reciprocal patterns of eve and $f t z$ expression since these genes exert opposite regulatory effects on $e v e$ and $f t z$ (summarized in Fig. 11).

\section{Experimental procedures}

Staged embryos from wild-type and balanced mutant stocks were fixed and stained with affinity-purified rabbit anti-eve antibodies, rabbit anti-ftz antibodies, or a mixture of both. This procedure was done exactly as described in Frasch et al. (1987). The identification of mutant genotypes was based on the fraction of embryos showing an altered eve expression pattern.

\section{Acknowledgments}

We thank Sean Carroll for many helpful suggestions and discussions, and Sean Carroll and Matt Scott for the $f t z$ antibody. We also thank Christiane Nüsslein-Volhard, Eric Wieschaus, Trudi Schüpbach, Ruth Lehmann, and Judith Lengyel for providing fly stocks. We are grateful to Judith Lengyel and Lily Mirels for critically reviewing the manuscript. This work was funded by grants from the National Institutes of Health and the Searle Scholars Program. M.F. was supported by a postdoctoral fellowship from the Deutsche Forschungsgemeinschaft.

\section{References}

Carroll, S.B. and M.P. Scott. 1985. Localization of the fushi tarazu protein during Drosophila embryogenesis. Cell 43: $47-57$.

Carroll, S.B. and M.P. Scott. 1986. Zygotically-active genes that affect the spatial expression of the fushi tarazu segmentation gene during early Drosophila embryogenesis. Cell 45: $113-126$.

Frasch, M., T. Hoey, C. Rushlow, H. Doyle, and M. Levine. 1987. Characterization and localization of the even-skipped protein of Drosophila. EMBO I. 6: 749-759.

Frohnhöfer, H.G. and C. Nüsslein-Volhard. 1986. Organization of anterior pattern in the Drosophila embryo by the maternal gene bicoid. Nature 324: 120-126.

Gergen, J.P. and E. Wieschaus. 1986. Dosage requirements for runt in the segmentation of Drosophila embryos. Cell 45: $289-299$.

Gloor, H. 1950. Schadigungsmuster eines Letalfaktors $(\mathrm{Kr})$ von Drosophila melanogaster. Arch. Jul. Klaus Stiftung 25: 3844.

Hafen, E., A. Kuroiwa, and W.J. Gehring. 1984. Spatial distribution of transcripts from the segmentation gene fushi tarazu of Drosophila. Cell 37: 825-831.

Harding, K., C. Rushlow, H.J. Doyle, T. Hoey, and M. Levine. 1986. Cross-regulatory interactions among pair-rule genes in Drosophila. Science 233: 953-959.

Howard, K. and P.W. Ingham. 1986. Regulatory interactions between the segmentation genes fushi tarazu, hairy, and engrailed in the Drosophila blastoderm. Cell 44: 949-957.

Ingham, P.W., D. Ish-Horowicz, and K.R. Howard. 1986. Correlative changes in homeotic and segmentation gene expression in Krüppel mutant embryos of Drosophila. EMBO $J$. 5: $1659-1665$.

Ingham, P.W. and A. Martinez-Arias. 1986. The correct activa- tion of Antennapedia and bithorax complex genes requires the fushi tarazu gene. Nature 324: 592-597.

Jäckle, H., D. Tautz, R. Schuh, E. Seifert, and R. Lehmann. 1986. Cross-regulatory interactions among the gap genes of Drosophila. Nature 324: 668-670.

Jürgens, G., E. Wieschaus, C. Nüsslein-Volhard, and H. Kluding. 1984. Mutations affecting the pattern of the larval cuticle in Drosophila melanogaster. Wilhelm Roux's Arch. Dev. Biol. 193: 283-295.

Knipple, D.C., E. Seifert, U.B. Rosenberg, A. Preiss, and H. Jäckle. 1985. Spatial and temporal patterns of Krüppel gene expression in early Drosophila embryos. Nature 317: 4044.

Laughon, A. and M.P. Scott. 1984. Sequence of a Drosophila segmentation gene: Protein structure homology with DNAbinding proteins. Nature 310: 25-31.

Lehmann, R. 1985. "Regionsspezifische Segmentierungsmutanten bei Drosophila melanogaster meigen." Ph.D. dissertation, Eberhard-Karls-Universitat, Tübingen, Germany.

Lehmann, R. and C. Nüsslein-Volhard. 1987. hunchback, a gene required for segmentation of an anterior and posterior region of the Drosophila embryo. Dev. Biol. 119: 402-417.

Macdonald, P.M., P.W. Ingham, and G. Struhl. 1986. Isolation, structure, and expression of even-skipped: A second pairrule gene of Drosophila containing a homeo box. Cell 47: $721-734$.

Mahoney, P.A. and J.A. Lengyel. 1987. The zygotic segmentation mutant tailless alters the blastoderm fate map of the Drosophila embryo. Dev. Biol. 122: 464-470.

Martinez-Arias, A. and P.A. Lawrence. 1985. Parasegments and compartments in the Drosophila embryo. Nature 313: 639642.

McGinnis, W., M.S. Levine, E. Hafen, A. Kuroiwa, and W.J. Gehring. 1984a. A conserved DNA sequence in homeotic genes of the Drosophila, Antennapedia, and bithorax complexes. Nature 308: 428-433.

McGinnis, W., R.L. Garber, J. Wirz, A. Kuroiwa, and W.J. Gehring. 1984b. A homologous protein-coding sequence in Drosophila homeotic genes and its conservation in other metazoans. Cell 37: 403-408.

Meinhardt, H. 1986. Hierarchical inductions of cell states: A model for segmentation in Drosophila. J. Cell Sci. (Suppl.) 4: $357-381$.

Nüsslein-Volhard, C. 1979. Maternal effect mutations that alter the spatial coordinates of the embryo of Drosophila melanogaster. In Determinants of spatial organization led. S. Subtelny, and I.R. Koenigsberg), pp. 185-211. Academic Press, New York.

Nüsslein-Volhard, C. and E. Wieschaus. 1980. Mutations affecting segment number and polarity in Drosophila. Nature 287: 795-801.

Nüsslein-Volhard, C., E. Wieschaus, and H. Kluding. 1984. Mutations affecting the pattern of the larval cuticle in Drosophila melanogaster. I. Zygotic loci on the second chromosome. Wilhelm Roux's Arch. Dev. Biol. 193: 267-282.

Nüsslein-Volhard, C., H. Kluding, and G. Jürgens. 1985. Genes affecting the segmental subdivision of the Drosophila embryo. Cold Spring Harb. Symp. Quant. Biol. 50: 145-154.

Petschek, J.P., N. Perrimon, and A.P. Mahowald. 1987. Regionspecific defects in 1(1)giant embryos of Drosphila melanogaster. Dev. Biol. 119: 175-189.

Scott, M.P. and A.J. Weiner. 1984. Structural relationships among genes that control development: Sequence homology between the Antennapedia, Ultrabithorax, and fushi tarazu loci of Drosophila. Proc. Natl. Acad. Sci. 81: 4115-4119. 
Strecker, T.R., K. Kongsuwan, J.A. Lengyel, and J.R. Merriam. 1986. Tailless, a zygotic mutant affecting the anterior and posterior regions of the Drosophila embryo. Dev. Biol. 113: $64-76$.

Tautz, D., R. Lehmann, H. Schnürch, R. Schuh, E. Seifert, A. Kienlin, K. Jones, and H. Jäckle. 1987. Finger protein of novel structure encoded by hunchback, a second member of the gap class of Drosophila segmentation genes. Nature 327: 383-389.

Wakimoto, B.T., F.R. Turner, and T.C. Kaufman. 1984. Defects in embryogenesis in mutants associated with the Antennapedia gene complex of Drosophila melanogaster. Dev. Biol. 102: $147-172$.

Wieschaus, E., C. Nüsslein-Volhard, and H. Kluding. 1984a. Krüppel, a gene whose activity is required early in the zygotic genome for normal embryonic segmentation. Dev. Biol. 104: 172-186.

Wieschaus, E., C. Nüsslein-Volhard, and G. Jürgens. 1984b. Mutations affecting the pattern of the larval cuticle in Drosophila melanogaster. III. Zygotic loci on the X chromosome and fourth chromosome. Wilhelm Roux's Arch. Dev. Biol. 193: 296-307. 


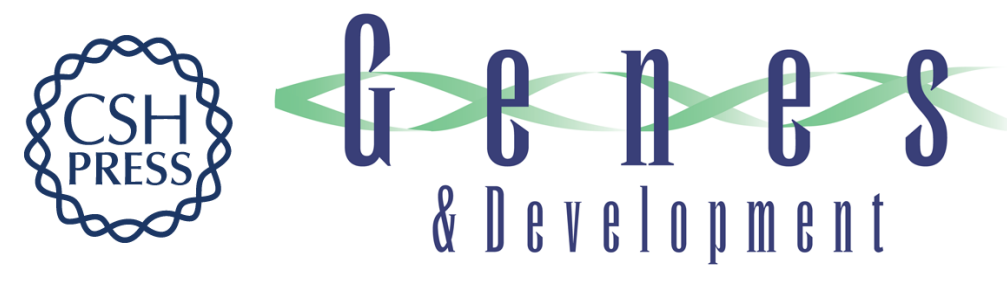

\section{Complementary patterns of even-skipped and fushi tarazu expression involve their differential regulation by a common set of segmentation genes in Drosophila.}

M Frasch and M Levine

Genes Dev. 1987, 1:

Access the most recent version at doi:10.1101/gad.1.9.981

References This article cites 32 articles, 2 of which can be accessed free at:

http://genesdev.cshlp.org/content/1/9/981.full.html\#ref-list-1

License

Email Alerting Receive free email alerts when new articles cite this article - sign up in the box at the top Service right corner of the article or click here.

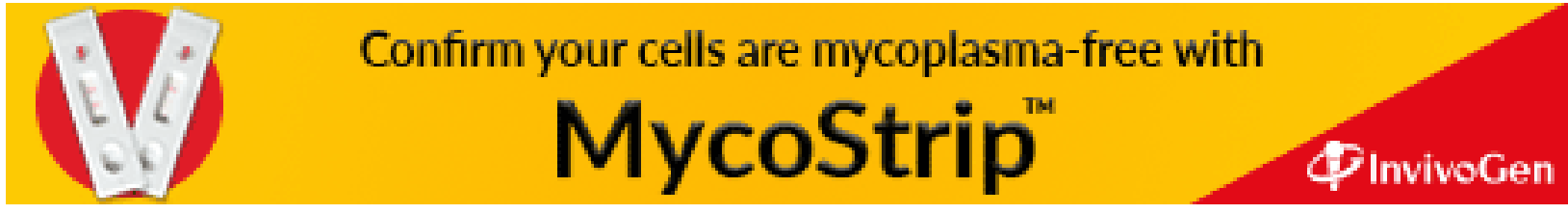

